\title{
PERAN KONFLIK KERJA-KELUARGA DALAM MEMEDIASI KONTRIBUSI DUKUNGAN SOSIAL TERHADAP KEPUASAN KERJA PADA PERAWAT PEREMPUAN
}

\author{
Alparisi Sirajuddin E M. Zein Permana \\ Universitas Jenderal Achmad Yani \\ E-mail:alparisi46@gmail.com; zein.permana@lecturer.unjani.ac.id
}

\begin{abstract}
This study to examine the role of work-family conflict in mediating relationships of social support and job satisfaction in female nurses. The approach used hierarchical regression analysis with social support as independent variable, job satisfaction as dependent variable, and work-family conflict (WFC) as mediator. Each variable was measured using a questionnaire given to participants consisting of 80 female nurses. The study found that social support had a significant positive contribution to nurse job satisfaction, and the contribution was mediated by work-family conflict.
\end{abstract}

Keywords: social support, work satisfaction, work-family conflict, nurses

\begin{abstract}
Abstrak
Penelitian ini bermaksud untuk menguji peran konflik kerja-keluarga dalam memediasi hubungan dukungan sosial dan kepuasan kerja pada perawat perempuan di rumah sakit. Penelitian ini adalah penelitian kuantitatif dengan menggunakan analisa regresi berjenjang (hierarchical regression) dengan dukungan sosial sebagai variabel independen, kepuasan kerja sebagai variabel dependen, serta konflik kerja-keluarga sebagai mediator. Setiap variabel diukur menggunakan kuesioner yang diberikan pada partisipan yang terdiri dari 80 perawat perempuan. Penelitian ini menemukan bahwa dukungan sosial memiliki kontribusi positif yang signifikan terhadap kepuasan kerja perawat, dan kontribusi terebut di mediasi oleh konflik kerja-keluarga.
\end{abstract}

Kata kunci: dukungan sosial, kepuasan kerja, konflik kerja-keluarga, perawat

\section{PENDAHULUAN}

Kepuasan kerja erat kaitannya dengan kinerja di lingkungan kantor (Landeweerd dan Boumans, 1988), sehingga tidak mengherankan bahwa konsep kepuasan kerja telah menarik banyak perhatian. Telah banyak cara pula untuk identifikasi berbagai komponen kepuasan kerja, mengukur kepentingan relatif masing-masing komponen dari kepuasan kerja dan menguji pengaruh komponen ini terhadap produktivitas pekerja (Burnard et al., 1999). Berbagai temuan yang berasal dari studi kuantitatif serta penelitian kualitatif telah dilaporkan dalam literatur tentang sumber kepuasan kerja. 
Secara sederhana kepuasan kerja dipahami sebagai bagaimana pekerjaan itu bisa merealisasikan harapan-harapan yang didapat individu terhadap pekerjaan yang ia jalani (Locke, 1969). Salah satu cara untuk mengetahui bagaimana seseorang itu puas atau tidak puas terhadap pekerjaan tersebut adalah dengan cara melihat apakah individu itu menyukai atau tidak menyukai pekerjaannya (Spector, 1997).

Ada dua bentuk umum untuk melakukan pengukuran terhadap kepuasan kerja, yaitu secara global dan komposit. Pendekatan global adalah melihat reaksi afektif terhadap keseluruhan pekerjaannya. Sementara pendekatan komposit adalah pendekatan dengan menguji sikap individu yang melihat kepuasan pekerjaan dari berbagai sudut pandang yang berbeda seperti rekan kerja, tunjangan, kondisi kerja, lingkungan pekerjaan itu sendiri, kebijakan dan prosedur, gaji, dan pengawasan (Spector, 1997).

Baik itu sudut pandang global maupun komposit terkait dengan penelitian kepuasan kerja tetap berfokus pada aspek kognitif, adapun masih adanya pendekatan melalui kebutuhan (motivasional) hanya sebagai pelengkap data saja (Spector, 1997). Hal ini berarti bahwa pendekatan penelitian kepuasan kerja terkait dengan apa yang dipersepsikan baik itu pikiran, perasaan, dan pendapat subjektif individu. Menariknya, sudut pandang subjektif ini juga berlaku pada persepsi individu dalam studi-studi yang terkait juga dengan dukungan sosial.

Dukungan sosial pada setiap orang mungkin akan berbeda secara persepsi, penilaian dan ingatan terhadap dukungan yang diberikan. Perbedaan inilah yang mungkin membuat dukungan sosial menjadi istimewa bagi orang yang menerima dukungan tersebut (Lakey \& Drew, 1997). Selain itu juga, dukungan sosial dipengaruhi kapan individu menerima dukungan itu (Sarason, Sarason, \& Pierce, 1995).

Terdapat beberapa studi yang menyatakan bahwa ada cara lain yang bisa dilakukan untuk melihat dukungan sosial dengan cara objektif yaitu dengan cara inter-observer. Seperti yang dilakukan oleh beberapa penelitian yang dilakukan Cohen, Lakey, Tiell, dan Nelly (2005). Namun jika dukungan sosial dilihat secara objektif maka dukungan sosial ini tidak menjadi sebuah variabel yang "istimewa" lagi, karena dukungan sosial akan bersifat mekanisme otomatis yang sudah terpola, sedangkan yang menjadikan dukungan sosial "istimewa" adalah sifat dukungan sosial yang mencerminkan apa yang betul-betul ada dalam diri individu terkait dengan kognisinya (Nolan et al, 1995; Lundh 1999; Aiken et al, 2001; Price, 2002; Wang, 2002).

Bruck, Allen, dan Spector (2002) menemukan hal lain terkait dengan kontribusi dukungan sosial terhadap kepuasan kerja. Bruck et al (2002) menemukan bahwa variabelvariabel yang disebut dalam meta-analisis Lu, Allison, dan Barriball (2004) menjadi sumber kepuasan kerja tidak terlepas dari bagaimana individu tersebut mengatasi Konflik kerja-keluarga atau work-familty conflict (WFC).

Konflik kerja-keluarga adalah istilah yang sering digunakan dalam menjelaskan konflik peran yang terjadi antara domain pekerjaan dan keluarga yang saling menuntut 
untuk dipenuhi. Renshaw (1976) mengatakan bahwa konflik kerja-keluarga adalah hasil dari interaksi domain stress pada pekerjaan dan tekanan dalam keluarga.

Ada 3 dimensi yang ada pada konflik kerja-keluarga, dimensi pertama berkaitan dengan waktu, dimensi ini didefinisikan bahwa waktu yang kita habiskan dalam satu peran menghalangi pemenuhan tanggung jawab kita pada peran yang lain. Kedua adalah dimensi perilaku, dimensi ini didefinisikan bahwa perilaku yang muncul pada peran tertentu tidak sesuai dengan peran tersebut. Maka dimensi ketiga ini disampaikan oleh Greenhaus dan Beutell (1985) mengenai strain-based conflict dimana tekanan dalam satu peran mempengaruhi pada peran lainnya.

Dari 3 dimensi tersebut bersifat bidirectional beberapa penelitian telah menemukan bukti empiris yang menunjukan hubungan antara Family Interference Work (FIW) dan Work Interference Family (WIF) yang merupakan penjabaran yang lebih luas dari konflik kerja-keluarga, (Aryee, Fields, \& Luk, 1999; Frone, Russell, \& Cooper, 1992). Hasil dari meta-analisis dari Kossek dan Ozeki (1998) menemukan bahwa skala konflik kerjakeluarga yang bersifat bidirectional berhubungan cukup kuat $(\mathrm{r}=0.31)$ dengan kepuasan kerja.

Pada hasil kajian sebelumya belum ada kerangka model teori yang secara spesifik menjadikan mediator hubungan antara variabel dukungan sosial dan kepuasan kerja. Padahal dukungan sosial merupakan sumber yang dapat meningkatkan kepuasan kerja Lu, Allison, dan Barriball (2004). Adapun penelitian yang menjadikan konflik kerjakeluarga menjadi variabel mediator adalah penelitian yang dilakukan Ford, et al. (2007) yang menunjukkan ada pengaruh dukungan dari tempat kerja (termasuk atasan) terhadap kepuasan perkawinan dengan di mediasi oleh konflik kerja-keluarga dan ada pengaruh dukungan dari keluarga (termasuk pasangan) terhadap kepuasan kerja dengan di mediasi oleh konflik kerja-keluarga.

Selain itu juga Soeharto (2015) melakukan penelitian terkait dengan dukungan suami dan kepuasan kerja yang dimediasi oleh konflik pekerjaan keluarga pada ibu yang bekerja. Penelitian ini melakukan uji model yang melibatkan 4 variabel yakni kepuasan kerja; konflik pekerjaan-keluarga; konflik keluarga-pekerjaan; dan dukungan suami. Penelitian ini setidaknya sudah mulai memasukkan konflik kerja-keluarga sebagai variabel mediator. Hanya saja konsep konflik kerja-keluarga yang digunakan masih memisahkan antara FIW dan WIF dalam variabel konflik kerja-keluarga, serta variabel dukungan sosialnya sangat spesifik pada dukungan suami. Artinya secara teoritis, penelitian yang menguji peran konflik kerja-keluarga sebagai variabel utuh, dan dukungan sosial secara umum dalam pendekatan yang global dalam kontribusinya terhadap kepuasan kerja masih belum dilakukan.

Berdasarkan hal tersebut, penelitian ini akan menguji peran konflik pekerjaankeluarga dalam memediasi hubungan dukungan sosial dan kepuasan kerja. Penelitian ini 
bersifat kontribusi, artinya melihat antara kontribusi variabel dukungan sosial, konflik kerja-keluarga, dan kepuasan kerja.

\section{METODE}

Data yang diperoleh adalah data dalam bentuk ordinal yaitu mengurutkan kategori respon dari tingkat yang "terendah" sampai tingkat yang "tertinggi” (Silalahi, 2012).

Sampel yang digunakan adalah perawat wanita. Rancangan pemilihan sampel dengan menggunakan penyampelan probabilitas yaitu seluruh unsur dalam suatu populasi memiliki kesempatan yang sama untuk dipilih dalam sampel. Dalam metode ini peneliti menggunakan metode penyampelan acak sederhana. Dikatakan sederhana karena pengambilan anggota sampel dari populasi dilakukan secara acak tanpa memperhatikan strata yang ada dalam populasi itu. Cara demikian dilakukan bila anggota populasi dianggap homogen atau memiliki kesamaan. Dengan demikian, anggota populasi yang dipilih akan mampu mewakili kondisi populasi.

Adapun karakteristik sampel pada penilitian ini adalah: perawat yang sudah menikah dan mempunyai anak; Mempunyai anak usia 0-13 tahun yang hidup bersama dalam satu rumah; dan suami yang bekerja.

\section{HASIL}

Pada regresi model 1 ini bertujuan untuk melihat peran dukungan sosial dalam berkontribusi terhadap kepuasan kerja. Maka untuk itu peneliti menggunakan analisis regresi berjenjang. Analisis regresi berjenjang dilakukan dengan regresi pada dua jenis model regresi yang berbeda, yaitu model 1, dan 2 yang sesuai dengan prediktor yang masuk pada regresi lalu setelahnya dibandingkan. Model 1 menjadikan dukungan sosial sebagai prediktor tunggal kepuasan kerja. Model 2 menjadikan dukungan sosial dan konflik kerja-keluarga sebagai prediktor kepuasan kerja.

Melalui analisis regresi berjenjang didapat hasil bahwa dukungan sosial memberikan kontribusi positif pada kepuasan kerja sebagaimana tertera pada tabel 1.

Tabel 1

Hasil Regresi

\begin{tabular}{clccccc}
\hline Model & & $R$ & $\begin{array}{c}R \\
\text { Square }\end{array}$ & $\begin{array}{c}\text { Adjusted } \\
\text { R Square }\end{array}$ & $\beta$ & Sig. \\
\hline 1 & Dukungan Sosial & 0.883 & 0.780 & 0.777 & 0.883 & 0.000 \\
& & & & & & \\
2 & Dukungan Sosial & 0.889 & 0.790 & 0.784 & 0.828 & 0.000 \\
& Konflik Kerja-Keluarga & & & & 0.112 & 0.065 \\
\hline
\end{tabular}


Dukungan sosial memiliki nilai koefisien regresi bertanda positif sebesar 0.833. Hal tersebut berarti bahwa setiap kenaikan dukungan sosial sebesar 1 (satu) satuan maka akan disertai dengan meningkatnya variabel Beta $(Y)$ yaitu kepuasan kerja sebesar 0.833. Ini menunjukan bahwa peran teman sebaya yang tinggi akan meningkatkan Kepuasan Kerja pada perawat.

Pada model 1 yaitu kontribusi dukungan sosial terhadap kepuasan kerja memiliki nilai adjusted $\mathrm{R}$ square sebesar 0.777 atau $77.7 \%$. Maka memiliki arti bahwa variabel dependen dalam penelitian ini yaitu kepuasan kerja dapat dijelaskan oleh variabel dukungan sosial yang memiliki kontribusi signifikan sebesar $77.7 \%$ terhadap munculnya kepuasan kerja.

Dukungan sosial pada model 2 memiliki nilai yang turun dari model 1 yaitu nilai koefisien regresi bertanda positif sebesar 0.828. Hal ini menunjukan bahwa setiap kenaikan satu satuan dukugan sosial akan di sertai peningkatan kepuasan kerja sebesar 0.828. ini menunjukan bahwa dukungan sosial yang tinggi akan meningkatkan kepuasan kerja. Sedangkan untuk nilai koefisien regresi konflik kerja-keluarga bertanda pertanda positif sebesar 0.112. Hal tersebut berarti bahwa setiap kenaikan konflik kerja-keluarga sebesar satu satuan maka kepuasan kerja akan meningkat 0.112 dengan asumsi bahwa variabel bebas yang lain dari model regresi adalah tetap.

Pada model 2 yaitu secara bersama-sama kontribusi dukungan sosial dan konflik kerja-keluarga terhadap kepuasan kerja memiliki nilai adjusted $R$ square sebesar 0.784 atau $78.4 \%$. Maka memiliki arti bahwa variabel dukungan sosial dan konflik kerjakeluarga secara bersama-sama memiliki kontribusi signifikan sebesar $78.4 \%$ terhadap munculnya kepuasan kerja.

Sedangkan kontribusi konflik kerja-keluarga terhadap kepuasan kerja memiliki adjusted $R$ square sebesar 0.007 yang di dapatkan dari hasil pengurangan 0.777 dikurangi 0.784. Maka memiliki arti bahwa variabel independen dalam penelitian ini yaitu perilaku menyontek dapat dijelaskan oleh variabel konflik kerja-keluarga yang memiliki kontribusi signifikan sebesar 7\% terhadap kepuasan kerja.

\section{PEMBAHASAN}

Berdasarkan pada hasil yang dilihat setelah dilakukan regresi pada dukungan sosial dan kepuasan kerja terlihat bahwa dukungan sosial memberikan dampak positif pada kepuasan kerja. Begitupun akan sebaliknya ketika dukungan sosial yang dirasa kurang oleh penerima yaitu perawat perempuan maka bisa menjadi salah satu penyebab ketidakpuasan terhadap pekerjaan.

Pengaruh dukungan sosial terhadap kepuasan kerja membenarkan hasil meta-analisis yang dilakukan oleh Lu, Allison, dan Barriball (2004) yang membuktikan bahwa 
dukungan sosial merupakan aspek penting sebagai sumber kepuasan kerja individu. Hal ini juga artinya mendukung temuan beberapa penelitian dukungan sosial yang spesifik terhadap kepuasan kerja (seperti dukungan rekan kerja; keluarga; suami-istri; atasan; lingkungan) seperti yang dilakukan Adamson et al. (1995), Nolan et al. (1995), Lee (1998), Tovey dan Adams (1999), Adams dan Bond (2000), Aiken et al. (2001), Price (2002), Tzeng (2002a, b), Wang (2002).

Hasil pada penelitian ini juga menunjukkan bahwa penelitian yang menggunakan dukungan sosial secara global dan umum masih secara signifikan dan besar kontribusinya terhadap kepuasan kerja. Hal ini karena berbagai penelitian sebelumnya mulai secara spesifik meneliti jenis dukungan-dukungan sosial yang lebih spesifik. Misalnya saja saja kondisi lingkungan kerja terhadap kepuasan kerja (Adamson et al, 1995; Nolan et al, 1995; Tovey \& Adams, 1999; Adams \& Bond, 2000; Tzeng, 2002a, b); dukungan sosial dalam bentuk interaksi sosial terhadap kepuasan kerja (Adamson et al, 1995; Nolan et al, 1995; Lee, 1998); dukungan sosial dalam bentuk hubungan baik dengan pasien terhadap kepuasan kerja (Lee, 1998; Tovey \& Adams, 1999); juga berbagai macam bentuk dukungan spesifik seperti dari suami (Aiken et al , 2001); atasan (Nolan et al, 1995; Lee,1998); dan rekan kerja (Price, 2002).

Individu memaknai puas dan tidak puas dalam pekerjaan itu sering kali berbeda. Contohnya ada yang merasa puas akan lingkungan kerjanya, namun tidak puas akan gajinya, ataupun sebaliknya seperti itu. Antara dua pendekatan ini menunjukan bahwa ada perbedaan yang penting dalam melihat dari sudut pandang mana kita akan melihat kepuasan kerja dalam sebuah penelitian, apakah dari sudut pandang global atau komposit.

Baik itu sudut pandang global maupun komposit terkait dengan penelitian kepuasan kerja tetap berfokus pada aspek kognitif, adapun masih adanya pendekatan melalui kebutuhan (motivasional) hanya sebagai pelengkap data saja (Spector, 1997). Hal ini berarti bahwa pendekatan penelitian kepuasan kerja terkait dengan apa yang dipersepsikan baik itu pikiran, perasaan, dan pendapat subjektif individu. Menariknya, sudut pandang subjektif ini juga berlaku pada persepsi individu dalam studi-studi yang terkait juga dengan dukungan sosial.

Dukungan sosial pada setiap orang mungkin akan berbeda secara persepsi, penilaian dan ingatan terhadap dukungan yang di berikan. Perbedaan inilah yang mungkin membuat dukungan sosial menjadi istimewa bagi orang yang menerima dukungan tersebut (Lakey \& Drew, 1997). Selain itu juga, dukungan sosial dipengaruhi kapan individu menerima dukungan itu (Sarason, Sarason, \& Pierce, 1995).

Penelitian ini telah membuktikan bahwa pengaruh dukungan sosial ternyata erat kaitannya dengan konflik kerja-keluarga. Artinya ketika dukungan sosial mempengaruhi kepuasan kerja, maka konflik kerja-keluarga lah yang menjadi perantara kontribusi yang terjadi tersebut. Berbagai penelitian menunjukkan faktor yang mempengaruhi konflik kerja-keluarga. Konflik kerja-keluarga dapat dipengaruhi adanya dukungan sosial yang 
berupa bantuan tenaga, nasihat, dan memahami kondisi istri akan mengurangi konflik kerja-keluarga yang dialami istri (Aycan \& Eskin, 2005; Kim \& Ling, 2001).

Hasil penelitian Erdwins, et al. (2001), menunjukkan ada hubungan dukungan sosial dengan konflik kerja-keluarga. Hasil meta-analisis yang dilakukan Ford, et al. (2007) menunjukkan ada pengaruh dukungan suami terhadap konflik kerja-keluarga isteri yang bekerja. Konflik kerja-keluarga juga menjadi variabel yang mempengaruhi. Penelitian yang dilakukan Grandey, et al. (2005) melaporkan konflik kerja-keluarga berhubungan negatif dengan kepuasan kerja. Pekerja yang mengalami konflik kerja-keluarga tinggi akan mengalami ketidakpuasan terhadap pekerjaan daripada pekerja yang mengalami konflik kerja-keluarga rendah. Hasil penelitian Jugde dan Colquitt (2004) pada staf akademik menunjukkan ada hubungan yang negatif antara konflik kerja-keluarga dengan kepuasan kerja. Hasil meta-analisis Kossek dan Ozeki (1998) menunjukkan ada pengaruh konflik kerja-keluarga terhadap kepuasan kerja. Dari berbagai penelitian tersebut, hanya menggambarkan pola hubungan terpisah, dan penelitian ini mencoba untuk menggambarkan pola hubungan lain, yakni konflik kerja-keluarga yang rupanya menjadi variabel perantara antara dukungan sosial dengan kepuasan kerja.

Berdasar uraian di atas dapat disimpulkan ada kesesuaian model teoritis dengan data faktual yang membuktikan bawa dukungan sosial berkontribusi terhadap kepuasan kerja yang di mediasi oleh konflik kerja-keluarga.

Berdasarkan hasil pengolahan data dan pembahasan, serta pengujian hipotesis yang telah dilakukan dengan menggunakan metode statistik. Maka dari penelitian ini dapat diberikan kesimpulan sebagai berikut: 1) Hasil pada penelitian ini juga menunjukkan bahwa penelitian yang menggunakan dukungan sosial secara global dan umum masih secara signifikan dan besar kontribusinya terhadap kepuasan kerja. Hal ini karena berbagai penelitian sebelumnya mulai untuk secara spesifik mengulik jenis dukungandukungan sosial yang lebih spesifik. 2) Ada kesesuaian model teoritis dengan data faktual yang membuktikan bawa dukungan sosial berkontribusi terhadap kepuasan kerja yang di mediasi oleh konflik kerja-keluarga. 3) Ada peran dari konflik kerja-keluarga dalam memediasi kontribusi antara dukungan sosial dan kepuasan kerja pada perawat rumah sakit.

\section{DAFTAR PUSTAKA}

Aiken, L. H., Clarke, S. P., Sloane, D. M., Sochalski, J. A., Busse, R., Clarke, H., \& Shamian, J. (2001). Nurses' reports on hospital care in five countries. Health affairs, 20(3), 43-53 
Aycan, Z., \& Eskin, M. (2005). Relative contributions of childcare, spousal support, and organizational support in reducing work-family conflict for men and women: The case of Turkey. Sex Roles, 53(7/8), 453-471

Andini, R. (2006). Analisis Pengaruh Kepuasan Gaji, Kepuasan Kerja, Komitmen Organisasional Terhadap Turnover Intention (Studi Kasus Pada Rumah Sakit Roemani Muhammadiyah Semarang) (Doctoral dissertation, Program Pasca Sarjana Universitas Diponegoro)

Baron, R. M., \& Kenny, D. A. (1986). The moderator-mediator variable distinction in social psychological research: Conceptual, strategic, and statistical considerations. Journal of Personality and Social Psychology, 51, 1173-1182

Bauer, D. J., Preacher, K. J., \& Gil, K. M. (2006). Conceptualizing and testing random indirect effects and moderated mediation in multilevel models: New procedures and recommendations. Psychological Methods, 11, 142-163

Barrera, M., \& Ainlay, S. L. (1983). The structure of social support: A conceptual and empirical analysis. Journal of community psychology, 11(2), 133-143

Bruck, C. S., Allen, T. D., \& Spector, P. E. (2002). The relation between work-family conflict and job satisfaction: A finer-grained analysis. Journal of vocational behavior, 60(3), 336-353

Burnard, P., Morrison, P., Phillips, C., 1999. Job satisfaction mongst nurses in an interim secure forensic unit in Wales.

Casper, W. J., Martin, J. A., Buffardi, L. C., \& Erdwins, C. J. (2002). Work--family conflict, perceived organizational support, and organizational commitment among employed mothers. Journal of occupational health psychology, 7(2), 99

Cohen, S., \& Hoberman, H. (1983). Positive events and social supports as buffers of life change stress. Journal of Applied Social Psychology, 13, 99-125

Cohen, S., Gottlieb, B. H., \& Underwood, L. G. (2000). Social relationships and health. In S. Cohen, L. Underwood, \& B. H. Gottlieb (Eds.), Social support measurement and intervention: A guide for health and social scientists (pp. 3-25). New York: Oxford University Press

Cohen, J. L., Lakey, B., Tiell, K., \& Neely, L. C. (2005). Recipient-provider agreement on enacted support, perceived support, and provider personality. Psychological Assessment (17), 375-378

Conrad, K.M., Conrad, K.J., Parker, J.E., 1985. Job satisfaction among occupational health nurses. Journal of Community Health Nursing (2), 161-173 
Duxbury, L., Higgins, C., \& Lee, C. (1994). Work-family conflict: A comparison by gender, family type, and perceived control. Journal of family Issues, 15(3), 449-466.

Dugguh, S. I., \& Dennis, A. (2014). Job satisfaction theories: Traceability to employee performance in organizations. Journal of Business and Management, 16(5), 11-18.

Erdwins.C. J., Buffardi, L. C., Casper.W. J., \& O`Brien, A. S. (2001). The Relationship of Women`s Role Strain to Social Support, Role Satisfaction and Self-Efficacy. Family Relations, 50(3), 230-238.

Fung-kam, L. (1998). Job satisfaction and autonomy of Hong Kong registered nurses. Journal of Advanced Nursing, 27(2), 355-363.

Frone, M. R., Yardley, J. K., \& Markel, K. S. (1997). Developing and testing an integrative model of the work-family interface. Journal of Vocational Behavior, 50, 145167.

Ford, M. T., Heinen, B. A., \& Langkamer, K. L. (2007). Work and Family Satis-faction and Conflict: A Meta-Analysis of Cross-Domain Relations. Journal of Applied Psychology, 92(1), 57-80.

Fox, M. L., \& Dwyer, D. J. (1999). An investigation of the effects of time and involvement in the relationship between stressors and work-family conflict. Journal of occupational health psychology, 4(2), 164.

Galinsky, E., Bond, T., \& Friedman, D.E. (1993). National study of the changing workforce. New York: Families and Work Institute

Greenhaus, J. H., \& Beutell, N. J. (1985). Sources of conflict between work and family roles. Academy of management review, 10(1), 76-88.

Greenhaus, J. H., \& Powell, G. N. (2012). The family-relatedness of work decision: A framework and agenda for theory and research, Journal of Vocational Behavior, 80(2), 246-255.

Herzberg, F., Mausner, B. and Snyderman, B.B. (1959), The Motivation to Work, 2nd ed., John Wiley \& Sons, New York, NY.

Hupcey, J. E. (1998). Clarifying the social support theory-research linkage. Journal of advanced nursing, 27(6), 1231-1241.

Haber, M. G., Cohen, J. L., Lucas, T., \& Baltes, B. B. (2007). The relationship between self-reported received and perceived social support: A meta-analytic review. American journal of community psychology, 39(1-2), 133-144.

Judge, T. A., Heller, D., Mount, M.K. (2002). Five-factor model of personality and job satisfaction: A meta-analysis, Journal of Applied Psychology, 87(3), 530-541. 
Kleinberg, S. J. (1989). The Shadow of the Mills: Working-Class Families in Pittsburgh, 1870-1907, Pittsburgh: University of Pittsburgh Press

Kahn, R. L.,Wolfe, D. M., Quinn, R. P., Snoek, J. D., \& Rosenthal, R. A. (1964). Organizational stress: Studies in role conflict and ambiguity. New York: Wiley.

Kossek, E. E., Pichler, S., Bodner, T., \& Hammer, L. B. (2011). Workplace social support and work-family conflict: A meta-analysis clarifying the influence of general and work-family-specific supervisor and organizational support. Personnel psychology, 64(2), 289-313.

Kuhlen, R.G., 1963. Needs, perceived need satisfaction opportunities, and satisfaction with occupation. Journal of Applied Psychology XLVII(1), 56-64.

Landeweerd, J.A., Boumans, N.P.G., 1988. Nurses' work satisfaction and feelings of health and stress in three psychiatric departments. International Journal of Nursing Studies 25, 225-234.

Locke, E.A. (1976), "The nature and causes of job satisfaction”, in Dunette, M.D. (Ed.), Handbook of Industrial and Organizational Psychology, Rand McNally, Chicago, IL, 1297-350.

Lakey, B., Adams, K., Neely, L., Rhodes, G., Lutz, C. J., \& Sielky, K. (2002). Perceived support and low emotional distress: The role of enacted support, dyad similarity, and provider personality. Personality and Social Psychology Bulletin, 28(11), 1546-1555.

Lakey, B., \& Drew, J. B. (1997). A social-cognitive perspective on social support. In G. R. Pierce, B. Lakey, I. G. Sarason, \& B. R. Sarason (Eds.), Sourcebook of theory and research on social support and personality. New York: Plenum

Lakey, B., \& Cassady, P. B. (1990). Cognitive processes in perceived social support. Journal of Personality and Social Psychology, 59(2), 337.

Lu, H., While, A. E., \& Barriball, K. L. (2005). Job satisfaction among nurses: a literature review. International journal of nursing studies, 42(2), 211-227.

Maslow, A., 1954. Motivation and Personality. Harper and Row, New York.

Nolan, M., Nolan, J., \& Grant, G. (1995). Maintaining nurses' job satisfaction and morale. British journal of nursing (Mark Allen Publishing), 4(19), 1149-1154.

Noor, M. N. (2002). Work-Family Conflict, Locus of Control, and Women`s Well-Being: Tests of Altenative Pathways. The Journal of Social Psychology, 142(5), 645-662.

O’Driscoll, M. P., Ilgen, D. R., \& Hildreth, K. (1992). Time devoted to job and off-job activities, interrole conflict, and affective experiences. Journal of Applied Psychology, 77, 272-279. 
Price, M. (2002). Job satisfaction of registered nurses working in an acute hospital. British journal of nursing, 11(4), 275-280.

Sandler, I. N., \& Barrera, M. Jr. (1984). Toward a multimethod approach to assessing the effects of social support. American Journal of Community Psychology, 12, 37-52.

Sarason, B. R., Shearin, E. N., Pierce, G. R., \& Sarason, I. G. (1987). Interrelations of social support measures: Theoretical and practical implications. Journal of Personality and Social Psychology, 52(4), 813.

Soeharto, T. N. E., \& Kuncoro, M. W. (2015). Dukungan Suami dan Kepuasan Kerja yang Dimediasi oleh Konflik Pekerjaan-Keluarga pada Ibu yang Bekerja. Jurnal Psikologi, 42(3), 207-216.

Sarason, B. R., Sarason, I. G., \& Gurung, R. A. R. (2001). Close personal relationships and health outcomes: A key to the role of social support. In B. Sarason \& S. Duck (Eds.), Personal relationships: Implications for clinical and community psychology (pp. 15-41). West Sussex, UK: Wiley

Shumaker, S. A., \& Brownell, A. (1984). Toward a theory of social support: Closing conceptual gaps. Journal of social issues, 40(4), 11-36.

Spector, P.E., 1997. Job Satisfaction: Application, Assessment, Causes, and Consequences. SAGE Publications, London.

Tzeng, H. M. (2002). Satisfying nurses on job factors they care about: A Taiwanese perspective. Journal of Nursing Administration, 32(6), 306-309.

Tejada, J. J., \& Punzalan, J. R. B. (2012). On the misuse of Slovin's formula. The Philippine Statistician, 61(1), 129-136

Tovey, E. J., \& Adams, A. E. (1999). The changing nature of nurses' job satisfaction: an exploration of sources of satisfaction in the 1990s. Journal of advanced nursing, 30(1), 150-158

Thomson, E, R \& Phua, F. T. T (2012). 'A Brief Index of Affective Job satisfaction, Organisation Management 37(3): 275-307

Ulber, S. (2012). Metodologi penelitian sosial. Bandung. PT Refika Aditama.

Waster, E.E, Berscheid, G.A \& Waster, G. W (1973). 'New Directions in Equity Research, Journal of Personality and Social Psychology 151-176

Worf, M.G., 1970. Need gratification theory: a theoretical reformulation of job satisfaction/dissatisfaction and job motivation. Journal of Applied Psychology 54, 8794 